\title{
Why Is the Estate Tax so Controversial?
}

\author{
Jens Beckert
}

Published online: 12 September 2008

(C) The Author(s) 2008. This article is published with open access at Springerlink.com

\begin{abstract}
There are some social issues whose significance for society nobody would seriously question but which nevertheless receive only scarce attention in sociological research. One of these is the bequest of private wealth from one generation to the next. It is currently estimated that about 550 billion dollars are transferred annually in the United States, amounting to more than $4 \%$ of the American gross national product (Havens and Schervish 1999). Not only is this a huge amount of wealth that changes ownership, but the bequest of wealth speaks to some of the core questions of sociological scholarship.
\end{abstract}

Keywords Estate tax - Gross national product - Wealth . Inheritance - Ownership

To begin with, the bequest of wealth is linked to questions of social inequality. To understand the intergenerational continuities of social inequality, it is not enough to look at the school system and the role of cultural and social capital available in families. The transfer of wealth plays an important role, as well (Arrondel et al. 1997; Havens and Schervish 2003a, b; Szydlik 2004). Since the distribution of wealth in society is hugely unequal, so is the transfer of this wealth mortis causa. The richest $10 \%$ of households in the United States owns almost $70 \%$ of all private wealth, while the bottom $50 \%$ of households must content itself with a meager share of 2.8\% (Davies et al. 2006: Table 9; Keister and Moller 2000). But, it is not only the consequences of the bequest of private wealth for the continuation of social

\section{J. Beckert $(\square)$}

Max-Planck-Institut für Gesellschaftsforschung,

Paulstr 3,

50676 Cologne, Germany

e-mail: Beckert@mpifg.de inequality that makes it a relevant topic for sociological research. Transfers also play an important role for family solidarity and conflict. Gifts or the expectation of an inheritance can contribute to family contact and mutual support within the family. At the same time, some of the bitterest fights in families involve inheritances.

Furthermore, inheritances play a pivotal economic role. In agrarian societies, the inheritance of land is the precondition for economic independence. In today's societies, the inheritance of wealth from parents can make the heirs independent from market success or, at the least, enhance their socioeconomic position. The possibility of bequeathing wealth may also be an important motivating factor for thrift and ambition if passing wealth to one's own kin is seen as important. Conversely, the inheritance of wealth can destroy this motivation in heirs whose living standard is secured independent of their own contribution. Finally, inheritances are sociologically relevant by being closely interwoven with the normative fabric of society. Fundamental normative principles like equality of opportunity, social justice, and the freedom of private property are affected.

Despite this obvious relevance of the topic, the bequest of wealth plays only a marginal role in current sociological scholarship. Already in the 1980, the topic was described as a "sociological lacunae" (McNamee and Miller 1989). Although there has been some more sociological scholarship on the issue in the intervening 20 years, it is far less than one would expect given the relevance of the topic (Beckert 2008; Kohli 1999; Spilerman 2000). To be sure, inheritance has not always been a neglected topic. On the contrary: in the nineteenth and early twentieth centuries, it was intensely debated in the social sciences. A good example is John Stuart Mill's ([1848] 1976, p. 889) assertion that inheritance law was matched in importance 
only by contract law and the determination of the status of the laborer. Alexis de Tocqueville ([1835] 1945, p. 50) was convinced that the issue of inheritance was so crucial to social development that "the legislator may rest from his labor" once he had regulated the laws governing it.

There are indications, however, that interest in the topic may be on the rise again within the social sciences. Estate taxation, one of the crucial areas of conflict in the regulation of the transfer of property, has become a topic of substantial political debate in the United States in recent years, and this has also prompted scholarly interest in the issue (Bartels 2005; Gates and Collins 2003; Graetz and Shapiro 2005). Estate taxation will remain on the political agenda, at least until a decision has been made on what will happen to the tax after 2010. If Congress does not take action, the tax rates from 2001 will become effective again in 2011. Indeed, from a longer historical perspective, estate taxation has been, since the late nineteenth century, one of the most controversial topics concerning the regulation of the transfer of property mortis causa. In the twentieth century, some of the most vocal conflicts over taxation in the United States have been about the federal estate tax. One of the more interesting questions about the estate tax is why it is such a controversial tax (Beckert 2008; Gates and Collins 2003).

There are a number of reasons that might lead one to assume the exact opposite. First, the tax plays only a small role in overall tax receipts of the state. Estate taxes have rarely ever contributed more than $2 \%$ to the federal budget. Second, due to the unequal distribution of wealth, only a tiny fraction of estates is actually paying estate taxes, which should make this tax politically unproblematic. There should be overwhelming support for it from the majority of voters. Third, the wealthy should have no special interest in questions regulating the distribution of their wealth after their death, since they are not affected by it.

This would lead to the conclusion that they should fight other wealth taxes but be neutral about the estate tax. Nevertheless, the fact that estate taxation is so controversial indicates that these arguments miss important dimensions. Bequests and their taxation seem to affect actors in profound ways and, thus, make them especially contested institutions.
In this article, I pursue the question of why estate taxation is such a deeply controversial issue, in spite of all of these factors suggesting that it should not be. I argue that the profoundly contested character of this tax cannot be attributed solely to the material position of the descendant testator and his or her heirs. Instead, I maintain that these conflicts have a much more profound background in the way this tax relates to the normative fabric of societies. I will show that bequests and their taxation relate in an especially conflictual way to the value-orders of modern societies. To that end, I distinguish four different principles that legitimize the intergenerational transfer of wealth: the family principle, the equality of opportunity principle, the fairness principle, and the community principle (Table 1).

The article has three parts. In the first part, I point to some problems that interest based explanations of the opposition to the estate tax encounter. In the second part, I show the role of social values in these conflicts based on the typology of legitimacy principles. In the last part, I demonstrate - using as example debates about the estate tax in two countries, the United States and Germany — why these normative foundations are relevant for the understanding of the conflicts over this tax.

\section{Economic and Private Interests in the Bequest of Wealth}

Seen from the perspective of economics and political science, the explanation of opposition to the estate tax seems straightforward. From an economic perspective, it can be argued that the taxation of bequests has such grave economic consequences in an economic order based on private capital investments that opposition serves to protect this economic order. To avoid a lasting impediment to private investments as the foundation of the capitalist economy, private property must be safeguarded and that also includes protecting the transfer of capital assets to children and grandchildren. The possibility to bequeath wealth allows for the long-term stability of capital investments and motivates people to thrift and ambition.

These arguments have, in fact, played an important role in the contentious debates around the inheritance tax. For

Table 1 Value principles in the transfer of wealth mortis causa

\begin{tabular}{lll}
\hline & Disposition by & \\
\cline { 2 - 3 } & Testator & State \\
\hline Individual/family & $\begin{array}{l}\text { Bequest within the family } \\
\text { Family principle }\end{array}$ & $\begin{array}{l}\text { Private redistribution to guarantee equality of opportunity (input-oriented) } \\
\text { Equality of opportunity principle }\end{array}$ \\
$\begin{array}{l}\text { Distribution to } \\
\text { Society }\end{array}$ & $\begin{array}{l}\text { Foundations } \\
\text { Community principle }\end{array}$ & $\begin{array}{l}\text { Redistribution via social policy (output-oriented) } \\
\text { Justice principle }\end{array}$ \\
\hline
\end{tabular}


Adam Smith, for instance, inheritance taxes were "more or less unthrifty taxes that increase the revenue of the sovereign, which seldom maintains any but unproductive laborers; at the expense of the capital of the people, which maintains none but productive" (Smith 1978 [1776]: 391). If assets are taxed without any distinction as to the kind of wealth and if the taxes are very high, such concerns would be justified. However, with moderate taxation levied in a sensible manner - in particular, one that does not endanger the survival of businesses - these fears seem unfounded. At any rate, it is hard to understand why the inheritance tax, in particular, is supposed to be so harmful to the economy. And, if it is not, the contentious nature of the taxation of inherited wealth cannot be adequately explained on economic-functionalist grounds.

The second explanation places the power of interest groups front and center. Since wealth and, thus, also inheritances are unequally distributed (Keister and Moller 2000; Szydlik 2004; Wolff 2002), the estate tax affects only a very small economic elite. How skewed the payment of estate taxes is can be seen from data provided by the Internal Revenue Service. From the Estate Tax Returns filed for 2004 it can be seen that only 19,000 estates had to pay the estate tax. This means the federal estate tax is assessed on less than $1 \%$ of annual deaths, which means that more than $99 \%$ of all estates are not taxed, thanks to the high exemptions. More than half of the estate tax revenue comes from the largest $7 \%$ of estates that are subject to taxation. In other words: more than half of the revenue from the estate tax is collected from only 1,366 estates. The 510 largest taxable estates in 2004, each with a taxable value of more than $\$ 20$ million, paid just under $\$ 8$ billion $(36 \%)$ of the entire estate tax revenue for that year (Internal Revenue Service 2008). The estate tax is, thus, paid chiefly by the estates of super rich testators, whose heirs would, conversely, derive the most benefit from the abolition of the estate tax.

It can be assumed that the small group of the extremely wealthy wields particular political influence. Since those affected fight the taxation of their wealth with all means at their disposal, opposition to this tax is virtually a given. This, no doubt, helps to explain the political opposition to the inheritance tax, which can be seen from the role of lobbying groups in the debates over this tax (Gates and Collins 2003).

Still, an explanation based entirely on the power of interest groups seems to be inadequate. For one, there are also other taxes - such as the income tax-that are paid predominantly by a relatively small group of very high income-earning taxpayers without these taxes being similarly controversial politically. Moreover, an explanation that invokes only economic interests makes it hard to understand why there are some owners of great wealth who are in favor of inheritance taxation (Carnegie 1992 [1889]; Gates and Collins 2003) and why, conversely, so many individuals who will never be affected by this tax repeatedly come out against the taxation of inheritances in opinion polls (Bartels 2005).

It would, therefore, seem that an explanation of the conflictual nature of inheritance taxes must also include factors other than arguments based on economic considerations and the power of interest groups. My sense is that two additional factors need to be considered: first, the extraordinarily high emotional charge that attaches to the way people deal with inherited wealth, which makes the transfer of wealth mortis causa a highly sensitive social issue and invests conflicts in this area with a special level of emotional energy. Second, different fundamental value principles of modern society clash when it comes to inheritance taxation; since these values have a relationship that is to some extent contradictory, they do not allow for a clear, unequivocal derivation of institutional regulations. In this article, I concentrate on the latter point.

\section{The Bequest of Wealth and the Multiplicity of Value Principles}

I contend that the conflictual nature of estate taxation arises from the variety of values associated with the transfer of wealth and the equivocal and contradictory ways these values are institutionally implemented. The interests of actors are likewise embedded in these contradictory value orders. The value orientations that are connected to the inheritance of wealth can be read from the political controversies over inheritance law and inheritance taxation (I have examined these debates over inheritance law and inheritance taxation in a comparative study of the United States, France, and Germany [Beckert 2007, 2008]). Two complementary normative questions are at stake here: who may dispose over the heritable property? Who has the right to take ownership of the heritable property?

\section{Estate Taxation and Property Rights}

The first question deals with the reach of individual property rights. One side of the debate holds that the right of the testator to dispose over the fate of his or her property, also post mortem, is an integral element of the owner's rights of freedom. A limitation on the transfer of property through inheritance taxation would be tantamount to a curtailment of the right of property, which would be reduced, as it were, to lifetime usufruct rights (Nozick 1974:168).

The other side holds to a conception of private property, which states that property rights are tied to the person of the owner and cease upon his or her death. Orestes Brownson, 
who was a member of the radical-liberal movement of Transcendentalism, penned an article entitled, "The Laboring Classes," which caused a tremendous stir when it was published in 1840. In it, he called for the introduction of confiscatory inheritance taxes by arguing that "[a] man shall have all he honestly acquires, as long as he himself belongs to the world in which he acquires it. But his power over his property must cease with his life, and his property must then become the property of the state, to be disposed of by some equitable law for the use of the generation which takes his place" (Brownson 1978 [1840]: 24).

However, the view that met with a much broader resonance within the legal discourse was far less radical. The notion that came to prevail increasingly in both AngloSaxon common law and in continental civil law was that inheritance law was not a natural law but a positive law, which was created by political decisions and could be revoked by the legislator at any time. The regulation of private inheritance rights, including the possibility of curtailing them, is, thus, subjected to the sovereignty of the legislator. This makes it possible to tax inheritances without having the tax come into conflict with the individual right of property, as interpreted by this position. In other words, a distinction is drawn between the protection of private property and the transfer of property mortis causa. But, this also means that inheritance taxation is not unequivocal with respect to the principle of private property. Rather, one can draw very different conclusions, all of which proceed in equal measure from the principle of individual private property.

\section{Four Orders of Justification of Estate Taxation}

The value principles prove far more multifaceted on the second question. It concerns the obligations of the testator with respect to the distribution of his property post mortem or the rights of the family and society (the state) to portions of the wealth that is left behind. How should inheritances be divided up? Four value principles collide in the answer to this question in modern western societies: the family principle, the equality of opportunity principle, the justice principle, and the community principle. These principles, which are, in part, simultaneously legitimated socially, can lead to quite different conclusions for the taxation of inheritances. Moreover, they are, taken by themselves, at least in part equivocal with respect to their institutional realization in inheritance tax law.

1. The family principle states that the property of the testator is not really individual property but property of the family as a legal entity that outlives the testator. This gives rise to a self-evident right of the family to have the wealth transferred to the testator's surviving family members. Strictly speaking, the process of inheritance is not a property transfer but merely a redistribution of the theoretical shares among family members. This principle, which dominated especially the German discourse on inheritance law-but played hardly any role in the United States - was articulated by Hegel, for example: "The natural dissolution of the family through the death of the parents, particularly of the husband, results in inheritance of the family's resources. Inheritance is essentially a taking possession by the individual as his own property of what in themselves are common resources" (Hegel 1991 [1821]: §178).

This value principle has been used to derive opposition to the taxation of inheritances. Inheritance taxes are rejected as an illegitimate and destructive interference in the unity of the family. Conversely, the handing down of wealth within the family is regarded as an important factor in promoting family solidarity (see Kohli 1999). Moreover, on a personal level, the transfer of property within the family is a significant factor in the transmission of identity. The inheritance symbolizes descent and continuation within the context of family continuity and makes a crucial contribution to what the French sociologist, Maurice Halbwachs, called "family memory."

However, the problematic issue of the relationship between family, state, and individual has also given rise, especially in liberal thought, to arguments for the taxation of inheritances. The expectation of an inheritance, it was argued, constrained the freedom of descendants because the inheritance also exercises control over the life decisions of the children. In addition, inheritances could damage the acquisitive desire of the descendants because their material circumstances were already secure. Finally, inheritances lead to destructive conflicts within the family (e.g., Mill 1976 [1857]).

2. The second value principle within the discourse on inheritance taxation is the equality of opportunity principle. Unlike the family principle, it calls much more strongly for the redistribution of inheritances by the state through taxation. The equality of opportunity principle is input-oriented in that it addresses the preconditions under which members of society enter into competition over scarce material resources. For one, on a macroeconomic level, the taxation of inheritances is supposed to counteract the dynastic concentration of wealth. An excessive concentration of wealth, so the argument goes, leads to the formation of power centers in society which can evade democratic control. This strand of conflict is evident, for example, in this passage from President Theodore Roosevelt's State of the Union address in 1906: "It is most desirable to encourage thrift and ambition, and a potent source of 
thrift and ambition is the desire on the part of the breadwinner to leave his children well off. This object can be attained by making the [estate] tax very small on moderate amounts of property left; because the prime object should be to put a constantly increasing burden on the inheritance of those swollen fortunes which it is certainly of no benefit to this country to perpetuate" (Roosevelt 1909: 29).

For another, and more influential still, the equality of opportunity principle plays an important role within the context of making equality of opportunity a reality. By taking the private property that exists within society and redistributing it as private property through inheritance taxation, members of society will be given equal material starting position. This, in turn, is the precondition for realizing the meritocratic principle as the central normative foundation for justifying social inequality within civic society. This line of argumentation has been especially important in estate tax debates in the United States and is evident also today. An example is the following quote from the financial investor Warren Buffet at a hearing of the Senate Finance Committee: "Dynastic Wealth, the enemy of meritocracy, is on the rise. Equality of opportunity has been on the decline. A progressive and meaningful estate tax is needed to curb the movement of a democracy toward a plutocracy. (Buffet 2007)

3. With respect to the conclusion to be drawn about the taxation of inheritances, the justice principle is closely tied to the equality of opportunity principle. However, unlike the latter principle, the justice principle is not focused on adjusting the starting conditions but seeks to correct the unequal success of market participants. It is result-oriented. Here, the taxation of inheritances is justified on the basis that the heirs have a greater financial ability to pay. "Strong shoulders," so the justification, can easily bear the burden of the tax, and by paying it, they can contribute to an improvement in the living conditions of members of society who have less or no success in the market place and, thus, to a just distribution of wealth in society overall. Under the equality of opportunity principle, revenues from the inheritance tax are to be evenly redistributed among young members of society, so as to create equal starting conditions for the "market struggle" (Max Weber). By contrast, the justice principle gives rise to the financing of redistribution by way of social policy that is intended to correct the outcomes of the market: the most urgent use to which revenues from the inheritance tax can be put is to fight poverty.

4. The community principle plays an important role as the fourth principle. In a sense, it combines the distrust toward the state as a mechanism of redistribution with the distrust of the family as the chief heir. This principle has strong roots especially in the United States. Here, the conviction (in part, also religiously grounded) that property has a communal obligation is front and center. A testator has the obligation to make sure that after his or her death the wealth will be put to a use that promotes the common good. This is done through the establishment of charitable foundations to which the wealth is transferred. This position rejects inheritance within the family on the grounds that children can waste the money or use it exclusively for private purposes. At most, family members have a moral right to be supported at an appropriate level. The rejection of redistribution by the state is normatively grounded in the notion that the testator knows much better how the wealth can be put to the best possible use for the common good. Of course, one factor that enters into this equation is that the wealth lives on tied to the name of the donor. By transferring the wealth to a foundation, its character as "special money" (Viviana Zelizer) is placed on a permanent footing. This might be one reason for the high degree of legitimacy enjoyed by the community principle and its attractiveness to the testator.

The most precise normative justification of the community principle was already offered by the essay, "The Gospel of Wealth," written in 1889 by the industrialist Andrew Carnegie. Carnegie demanded that wealth that was not transferred to foundations already during the owner's lifetime should be subjected to high inheritance taxes, for "[t]he man who dies thus rich dies disgraced" (Carnegie 1992 [1889]: 140). The testator who dies rich did not live up to his moral obligation to use his superior abilities to solve pressing social problems. The inheritance tax was to create an incentive to set up foundations and make the bequeathal of wealth within the family "expensive." Economic studies based on simulations show this kind of link between the level of the inheritance tax and the willingness to place wealth into foundations (Joulfaian 2000).

\section{The National Context of the Orders of Justification}

These four value principles, which are common in the discourse on inheritance taxation, legitimate different ways of dealing with inherited wealth. A look at the debate over the estate tax in the United States and Germany reveals that different justifications stand at the center of the positions that are staked out. In the process, the conflicts are in each instance structured in accordance with a binary contrast of two dominant value principles, from which contrary 
conclusions are derived with respect to the taxation of inheritances (Beckert 2008).

In the US, opponents of inheritance taxation argue primarily with an interpretation of property law that includes the unrestricted right to dispose over property also after the owner's death. This reasoning is linked with the concern that this kind of taxation could have negative effects on the entrepreneurial spirit. Inheritance taxes, so the argument, demotivate economic ambitions and endanger especially small companies, whose existence is supposedly the very backbone of the economic foundation of democratic freedoms.

On the other side, the US has a long tradition of criticism of the transfer of wealth between generations, one that is grounded primarily in the equality of opportunity principle and the community principle. Inheritances seem "unAmerican," because they violate the principle of equal opportunity and, in a sense, perpetuate feudal privileges. This argumentative context is evident, for example, in the earlier quote from Warren Buffet.

Arguments in the US that are critical of inheritance pick up the issue of equal opportunity, but they add to it perspectives that are critical of the state and-compared to the equality of opportunity principle - arise from a different view of the relationship between the individual and society. Instead of assigning to the state the central role as an agent of redistribution, estate taxation is seen merely as a fallback option to create incentives for the establishment of charitable foundations. The community principle also encompasses a specific relationship between individualism and social community: the establishment of charitable foundation is community-oriented to the extent that the income from the endowment is used for causes that promote the common good. At the same time, the establishment of foundations is a radically individualistic act since foundations serve to perpetuate the name of the donor beyond death and because the definition of what the common good is lies entirely within the discretion of the donor.

If one looks at the value principles that dominate the discourse on inheritance taxation in Germany, one can identify characteristic differences to the US. In Germany, opposition to inheritance taxation is grounded primarily in the family principle, which makes inheritance taxes seem like an illegitimate interference on the part of the state in the sphere of the family. Economic arguments also place the role of family businesses front and center. But, the arguments of those in favor of the inheritance tax are also different from the US as they refer primarily to the justice principle. Inheritance taxes are deemed legitimate because inheritances result in a boost to the wealth of heirs, and it is, therefore, just if they relinquish a part of the gain to finance the tasks of the community. Inheritance taxes are part of the context of social policy; they serve to correct the unequal success of members of society in the market. The inputoriented principle of equal opportunity and the focus on charitable foundations play a subordinate role, at best.

The differing justifications in the US and Germany help us to understand why the taxation of bequests in the US prompted even more intense controversies than it did in
Fig. 1 Top rates of inheritance taxes in the United States and in Germany 1907-2007

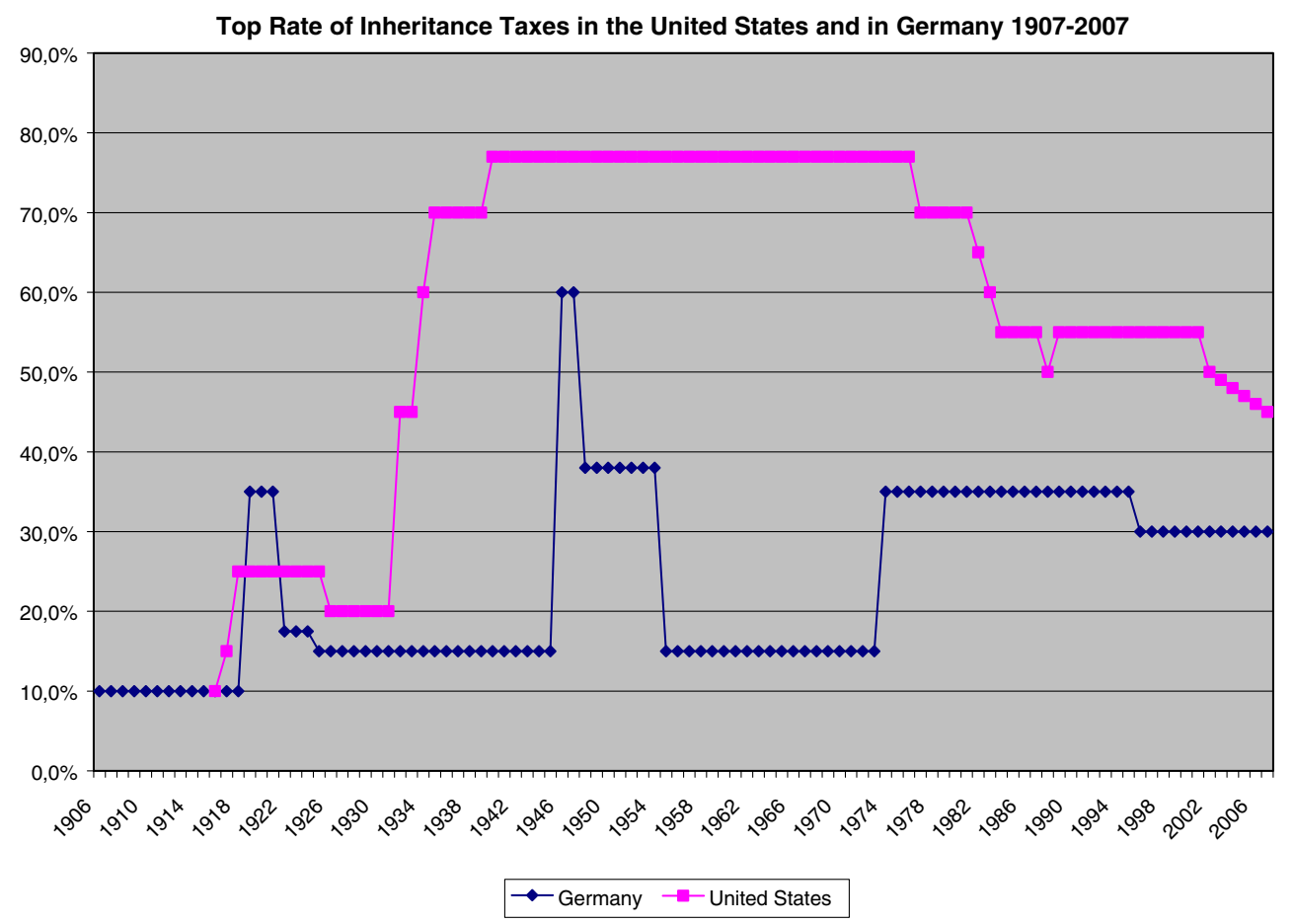


Germany and why inheritance taxation in the US was higher than in Germany for long stretches of the twentieth century (Fig. 1). While the revenue from the inheritance and gift taxes in Germany in 2000 was 37 euro per capita, in the US, the figure was about 89 dollars (Schupp and Szydlik 2004 for Germany, author's calculation for the US). These differences can be linked to the normative principles that structure estate tax discourses in both countries. Within the American context of justification, inheritances are problematic because they lead to unequal material starting positions for members of society. The only way to correct that is to reduce this inequality: either by redistributing inheritances in equal shares to members of society or by segregating them through a transfer to charitable foundations. In Germany, by contrast, it is not so much the unequal starting position that seems problematic, as the social inequality that is reproduced by the market; that being so, members of society who are not successful in the marketplace have a legitimate claim to support in the spirit of solidarity — also from heirs.

This result-focused view of the problem of social inequality does not point automatically to a correction in unequal starting positions; instead, it faces the problem of how to generate sufficient financial resources to create satisfactory living conditions for those without success in the marketplace. Where these funds come from-whether from inheritances, income, corporate profit, or other taxesis, in the final analysis, irrelevant and largely a question of pragmatic political decisions. Inheritances are one source of money for the state, but there is no reason to tax bequests specifically. During the period when estate taxation was especially contested, between 1870 and 1925, the modern tax system with the income and value-added tax as its crucial pillars was only in its infancy. That was the reason, not least, why the tax discourse at the time was directed at inheritances as a possible source of revenue. The consolidation of the modern tax system, the weak legitimacy attached to redistribution aimed at equal opportunity, and the strong family-oriented opposition to inheritance taxation help us to understand why inheritance taxation in Germany is less important in the political discourse than is the case in the US and why for much of the twentieth century inheritance taxation in the US was much higher than in Germany.

\section{Conclusion}

The investigation of discourses on estate taxation in the United States and Germany provides insight into how deeply the issue of estate taxation is related to fundamental value principles of these societies. These value principles, however, do not lead to a clearly defined path for the institutional regulation of the taxation of bequests. Instead, contradictory consequences flow from one or the other principle or from value principles that are simultaneously relevant in the political discourse. Beyond material interests and the power of interest groups, these conflicting value principles contribute to the highly contested character of estate taxation. In many cases, their political articulation runs counter to the material interests of their proponents. Moreover, the discursive structures exhibit long continuities.

Even in current debates on estate taxation, one can observe the persistence of discursive rifts that were formed already at the time of the American Revolution and have been reactivated in political discourses on the issue ever since. While the various positions have exerted their influence to different degrees at different times, they have never fully disappeared from the discourse. Although estate tax debates in the United States since the 1980s show a clear dominance of positions advocating the abolition of estate taxation on economic grounds, arguments concerning the prevention of dynastic wealth and the realization of equal opportunities have continuously been used to defend the tax. At the same time, the protection of the family, the most important argument against inheritance taxes in Germany, finds little resonance in the American discourse.

In more general terms, the investigation of discourses on estate taxation demonstrates the significance of legitimacy for institutional propositions that derives from broader value orientations. Actors must legitimate their demands in public discourse by invoking not their particularistic advantages, but the general good. To generate political support, positions must be framed with reference to broader values that have legitimacy in the social arena. Actors aim for "justifiable action" (Thévenot 2002: 183). The extent to which the value orientations expressed in these discursive frames are consequential for institutional change reveals that socially shared value orientations are a powerful element of social development.

Open Access This article is distributed under the terms of the Creative Commons Attribution Noncommercial License which permits any noncommercial use, distribution, and reproduction in any medium, provided the original author(s) and source are credited.

\section{Further Reading}

Arrondel, L., Masson, A., \& Pestieau, P. 1997. Bequest and inheritance: Empirical issues and France-U.S. comparison. In G. Erreygers, \& T. Vandevelde (Eds.), Is inheritance legitimate (pp. 89-125). Berlin: Springer.

Bartels, L. M. 2005. Homer gets a tax cut: inequality and public policy in the American mind. Perspectives on Politics, 3, 15-31.

Beckert, J. 2007. The longue durée of inheritance law. discourses and institutional development in France, Germany, and the United 
States since 1800. Archives européennes de Sociologie XLVIII, 1, 79-120.

Beckert, J. 2008. Inherited wealth. Princeton: Princeton University Press Translated by Thomas Dunlap.

Brownson, O. 1978 [1840]. The laboring classes. In O. Brownson (Ed.), The Laboring Classes (pp. 5-24). Delmar: Scholars' Facsimiles Reprints.

Buffet, W. 2007. Video clip and tanscript of warren buffetts opening statement before the Senate Finance Committee holding a hearing on estate taxes (November 14, 2007). http://www.cnbc. com/id/21791804/. Accessed at 2.15.2008.

Carnegie, A. 1992 [1889]. The gospel of wealth. In J. F. Wall (Ed.), (Hg.): The andrew carnegie reader (pp. 129-154). Pittsburgh: University of Pittsburgh Press.

Davies, J. B., Sandstrom, S., Shorrocks, A., \& Wolff, E. N. 2006. The world distribution of household wealth, unpublished manuscript. http://www.iariw.org/papers/2006/davies.pdf. Accessed at February 15,2008

de Tocqueville, A. 1980 [1835]. Democracy in America (vol. 2). New York: Knopf (orig. 1945)

Gates Jr., W. H., \& Collins, C. 2003. Wealth and our commonwealth: why America should tax accumulated fortunes. Boston: Beacon.

Graetz, M. J., \& Shapiro, I. 2005. Death by a thousand cuts the fight over taxing inherited wealth. Princeton: Princeton University Press.

Havens, J. J., \& Schervish, P. G. 2003a. Millionaires and the millennium:New estimates of the forthcoming wealth transfer and the prospects for a golden age of philanthropy. Boston: Boston College Social Welfare Research Institute.

Havens, J. J., \& Schervish, P. G. 2003b. Why the $\$ 41$ trillion wealth transfer estimate is still valid: a review of challenges and questions. The Journal of Gift Planning, 7(11-15), 47-50.

Hegel, G. F. 1991. In A. W. Wood (Ed.), Elements of the philosophy of right. Cambridge: Cambridge University Press.

Internal Revenue Service 2008. Estate tax returns filed for 2004 descendents. Values for Tax Purposes, by Tax Status and Size of Gross Estate. SOI Estate Tax Data Tables, Selected Years of Death. http://www.irs.gov/taxstats/indtaxstats/article/0, id= 96442,00.html\#3. Accessed at February 15, 2008.

Joulfaian, D. 2000. Estate taxes and charitable bequests by the wealthy nber working paper series 7663. Cambridge: NBER.
Keister, L., \& Moller, S. 2000. Wealth inequality in the United States. Annual Review of Sociology, 26, 63-81.

Kohli, M. 1999. Private and public transfers between generations: linking the family and the state. European Societies, 1, 81-104.

McNamee, S. J., \& Miller Jr., R. K. 1989. Estate inheritance: a sociological lacuna. Sociological Inquiry, 59, 7-29.

Mill, J. S. 1976 [1848]. Principles of political economy. Fairfield: Kelley.

Nozick, R. 1974. Anarchy, State, and Utopia. Oxford: Blackwell.

Roosevelt, T. 1909. Message to the Senate and House of Representatives, 3.12.1906 S. VII. In House of Representatives: papers relating to the foreign relations of the United States, Part 1. Washington: Government Printing Office.

Schupp, J., \& Szydlik, M. 2004. Erbschaften und schenkungen in deutschland: wachsende fiskalische bedeutung der erbschaftssteuer. DIW Berlin, 71(5), 59-65 Wochenbericht.

Smith, A. 1976 [1776]. The wealth of nations. Chicago: University of Chicago Press.

Spilerman, S. 2000. Wealth and stratification processes. Annual Review of Sociology, 26, 497-524.

Szydlik, M. 2004. Inheritance and inequality: theoretical reasoning and empirical evidence. European Sociological Review, 20, 31-45.

Thévenot, L. 2002. Conventions of co-ordination and the framing of uncertainty. In E. Fullbrook (Ed.), Intersubjectivity in economics (pp. 181-197). London: Routledge.

Wolff, E. N. 2002. Top heavy. A study of the increasing inequality of wealth in America. 2 Aufl. New York: The New Press.

Jens Beckert is a director at the Max Planck Institute for the Study of Societies in Cologne, Germany and author of Beyond the Market: The Social Foundation of Economic Sociology (Princeton University Press). This article is based on his most recent book, Inherited Wealth (Princeton University Press). Most parts of this article have been translated from the German by Thomas Dunlap. 